\title{
PERAN NOTARIS DALAM PENGESAHAN PENDIRIAN PERSEROAN TERBATAS MELALUI SISTEM ADMINISTRASI BADAN HUKUM (SABH)
}

\author{
Oleh : Fauzan Salim \\ Staff Perusahaan Sawit PT.Alam Barajo Prima \\ Kabupaten Tanjung Jabung Barat - Jambi \\ Email :ojanfauzan1989@gmail.com
}

\begin{abstract}
ABSTRAK
SABH adalah Sistem Administrasi Badan Hukum dalam permohonan penyelesaian badan hukum Perseroan Terbatas yang dilakukan secara elektronik menggunakan media Internet secara online. Sebuah prosedur adalah kunci dari suatu sistem hukum yang berlaku, tanpa prosedur yang benar dan sesuai dengan undang-undang serta ketentuan yang berlaku, maka seluruh sistem tersebut akan timpang, sehingga prosedur memegang peranan penting dalam sebuah keberlangsungan suatu sistem. Begitu pula dalam sistem pengesahan pendirian Perseroan Terbatas, dimana peranan notaris adalah sebuah mata rantai dari seluruh prosedurnya..Metode penulisan yaitu metode penelitian hukum yuridis normatif, metode pendekatan yang digunakan adalah metode pendekatan perundang-undangan dan metode pendekatan konseptual, pengumpulan bahan hukum dalam penelitian ini adalah bahan hukum primer, bahan hukum sekunder, dan bahan hukum tersier, yang dengan caramenginventarisasikan,menginterprestasikan, mengsistematisasikan, mengevaluasi, mengklasifikasikan serta penarikan kesimpulan. Hasil penelitian Jurnal ini menunjukan bahwa pendirian Perseroan Terbatas melalui SABH dimulai dengan dilakukannya permohonan pemesanan.nama perseroan dan ditindak lanjuti dengan pembuatan akta pendirian PT. Berdasarkan kuasa yang diberikan oleh para pendiri kepada Notaris sebagai pemohon, pemohon melakukan pembayaran PNBP pengesahan dan BN/TBN. Selanjutnya, dalam jangka waktu 60 (enam puluh) hari terhitung dari tanggal pembuatan akta, Notaris melakukan pengisian data PT dan menyampaikan kepada Kementerian Hukum dan HAM sesuai dengan format SABH secara elektronik.
\end{abstract}

Kata Kunci : Notaris, Pendirian Perseroan Terbatas, SABH 


\begin{abstract}
$\mathrm{SABH}$ is the Legal Entity Administration System in the application settlement of limited liability legal entities conducted electronically using internet media online. A procedure is the key of an applicable legal system, without proper procedures and in accordance with the law and the provisions that apply, then the entire system will lame, so the procedure plays an important role in a the sustainability of a system. Likewise in the system of legalization of establishment Limited Liability Company, where the role of the notary is a chain of all procedures. The writing method is the normative legal research method, the approach used is the legal approach method and the conceptual approach method, the collection of legal materials in this study are primary legal materials, secondary legal materials, and tertiary legal materials, which with how to inventory, interpret, systematize, evaluate, classify and draw conclusions. The results of this thesis study show that the establishment of a Limited Liability Company through SABH begins with an order request. the name of the company and followed up with the drafting of the establishment of PT. Based on the power granted by the founders to the Notary as the applicant, the applicant pays the endorsement PNBP and BN / TBN. Furthermore, within a period of 60 (sixty) days from the date of drafting, the Notary will complete the PT data and submit it to the Ministry of Law and Human Rights in accordance with the SABH format electronically.
\end{abstract}

Keywords: Notary, Establishment of Limited Liability Company, SABH 


\section{Latar Belakang Masalah}

Kebutuhan akan notaris terutama pada bidang usaha, khususnya tumbuh kembangnya perseroan terbatas sebagai badan hukum terutama pada proses pendiriannya, oleh masyarakat global saat ini merupakan kebutuhan yang primer.Disamping memenuhi ketentuan undang-undang, dalam hal ini khususnya undang-undang perseroan terbatas, peran Notaris diharapkan dapat memberikan perlindungan hukum bagi masyarakat dalam menjalankan usahanya.Notaris sebagai Pejabat Umum diberikan perlindungan hukum oleh undangundang dalam rangka memberikan kesaksian di pengadilan, ${ }^{1}$ dengan demikian kehadiran akta otentik yang merupakan sebuah produk hukum yang dilahirkan oleh notaris adalah pendukung terciptanya konsep kepastian hukum yang merupakan cikal bakal keadilan.Kegiatan Notaris merupakan kegiatan tertata sesuai dengan prosedur dan kewenangan yang dimiliki dalam artian bahwa Notaris dan para pihak dengan alat bukti tertulis yang bersifat otentik mengenai keadaan, peristiwa, atau perbuatan hukum harus tersimpan dengan baik. Seperti yang diamanahkan oleh Pasal 1 angka (13) UndangUndang Republik Indonesia Nomor 2 tahun 2014 "Protokol Notaris adalah kumpulan dokumen yang merupakan arsip negara yang harus disimpan dan dipelihara oleh Notaris sesuai dengan ketentuan peraturan perundang-undangan," dan Pasal 16 huruf (b) mengatur bahwa "membuat Akta dalam bentuk Minuta Akta dan menyimpannya sebagai bagian dari Protokol Notaris ${ }^{2}$

Ide dasar negara hukum baik dalam konsep "rechtsstaat" maupun "the rule of law" sasaran utamanya adalah perlindungan hak-hak dasar manusia. Dalam konsep rechtsstaat perlindungan hak-hak dasar diwujudkan melalui asas legalitas. Dengan asas tersebut, hukum harus dipositifkan, artinya hukum harus dibentuk secara sadar dan dituangkan dalam bentuk yang resmi dan pasti seperti dibuatnya Undang-Undang Nomor 02 Tahun 2014 tentang Perubahan Atas UU No. 30 Tahun 2004 tentang Jabatan Notaris. ${ }^{3}$

Notaris sebagai pejabat umum dituntut tanggung jawab terhadap akta yangdibuatnya.Apabila akta yang dibuat dibelakang hari mengandung sengketa maka hal ini perlu dipertanyakan, apakah akta itu merupakan kesalahan notaris atau kesalahan para pihak yang tidak memberikan dokumen dengan sebenar-benarnya dan para pihak

${ }^{1}$ Aman, Perlindungan Hukum Notaris Dalam Melaksanakan Rahasia Jabatan Recital Review, Vol 2 No 1 (2019): Volume 1, Nomor 2, Juli2019.

${ }^{2}$ Syamsir, Elita Rahmi, Yetniwati, Porspek Cyber Notary Sebagai Media Penyimpanan Pendukung Menuju Profesionalisme Notaris,Recital Review, Magister Kenotariatan Universitas JambiVol 2 No 1 (2020): Volume 2, Nomor 1, Januari 2020

${ }^{3}$ Bahder Johan Nasution, Penerapan Sanksi Administrasi Sebagai Sarana Pengendali Pembatasan Terhadap Kebebasan Bertindak Sebagai Notaris, Recital Review, Magister Kenotariatan Universitas Jambi Vol 2 No 1 (2020): Volume 2, Nomor 1, Januari 2020 
memberikan keterangan yang tidak benar diluar sepengetahuan notaris atau adanya kesepakatan yang dibuat antara notaris dengan salah satu pihak yang menghadap.Apabila akta yang dibuat notaris mengandung cacat hukum karena kesalahan notaris baik karena kelalaian maupun kesengajaan notaris itu sendiri, maka notaris itu harus memberikan pertanggung jawaban baik secara moral maupun secarahukum. ${ }^{4}$

"Perjanjian" pendirian perseroan terbatas yang dilakukan oleh para pendiri tersebut dituangkan dalam suatu akta notaris yang disebut dengan Akta Pendirian".Akta Pendirian ini pada dasarnya mengatur berbagai macam hak-hak dan kewajiban para pihak pendiri perseroan dalam mengelola dan menjalankan perseroan terbatas tersebut.Hak-hak dan kewajiban-kewajiban tersebut yang merupakan isi perjanjian selanjutnya disebut dengan "Anggaran Dasar" perseroan, sebagaimana ditegaskan dalam Pasal 8 ayat (1) Undangundang Perseroan Terbatas.Pemberian status hukum Perseroan Terbatas tersebut harus memenuhi persyaratan tertentu yaitu setelah akta pendiriannya mendapat pengesahan dari Menteri Kehakiman sebagaimana ditentukan dalam Pasal 7 ayat (4) Undang-undang Perseroan Terbatas yang menyatakan sebagai berikut: "Perseroan memperoleh status badan hukum pada tanggal diterbitkannya Keputusan Menteri mengenai pengesahan badan hukum Perseroan".

Pada sistem manual atau sistem lama dalam proses pengesahan akta Perseroan Terbatas, pekerjaan dilakukan secara manual mulai dari penerimaan berkas yang meliputi pengecekan nama, pembayaran dan pembuatan kartu kendali. Dokumen-dokumen pada proses manual ini seluruhnya masih berbentuk kertas laporan, baik pendirian, persetujuan maupun laporannya.

Dengan cara kerja sistem manual ini, sering timbul masalah keterlambatan, hal ini sangat mungkin terjadi karena para petugas harus memeriksa satu persatu permohonan yang masuk, sedangkan jumlah permohonan yang masuk jauh lebih banyak dari kapasitas petugas yang ada. Risiko terjadinya kesalahan-kesalahan dalam pemeriksaan dokumen maupun buktibukti kelengkapan dokumen yang dimasukkan ke Departemen Kehakiman dan Hak Asasi Manusia menjadi lebih besar, dan tingkat keakurasian pemeriksaaannya pun menjadi rendah.

Bagi para notaris sistem manual ini merupakan sesuatu yang dilematis.Para pemakai jasa notaris selalu mengharapkan agar proses pengesahan perseroan dapat berjalan dengan cepat dan tepat waktu, karenanya tidak jarang jika masyarakat beranggapan bahwa notaris adalah juga "biro jasa" yang bertanggung jawab terhadap keakuratan dan ketepatan waktu dalam penyelesaian proses pengesahan.

Seiring perkembangan jaman, tampaknya UUPT sendiri sudah mulai tidak mampu untuk menampung dinamika dunia usaha, hal ini dibuktikan dengan banyaknya peraturanperaturan pendukung agar dunia usaha tetap pada koridor hukum yang seharusnya.Salah satunya pada tahun 2000, pemerintah mengeluarkan peraturan baru yang berkenaan dengan

${ }^{4}$ Putri AR, Perlindungan Hukum Terhadap Notaris (Indikator Tugas-Tugas Jabatan Notaris Yang Berimplikasi Perbuatan Pidana), Jakarta, Sofmedia, hlm. 8. 
pendaftaran perseroan terbatas melalui sistem administrasi badan hukum SABH (dulu disebutSISMINBAKUM ).

Kehadiran peraturan-peraturan dalam bidang usaha menjadi acuan pelaku usaha dalam berkegiatan dan dalam proses pendirian Perseroan Terbatas, dimana notaris memiliki peranan yang cukup dominan dalam legalisasi Perseroan Terbatas secara spesifik berkenaan dengan pendirian Perseroan Terbatas baik pengesahan pendirian Perseroan Terbatas secara manual maupun melalui SABH secara elektronik, serta efektifitas hukumnya dalam masyarakat maupun tanggung jawab yang dipikul oleh notaris dalam melaksanakan perannya dalam proses pengesahan pendirian Perseroan Terbatas

Sistem Administrasi Badan Hukum atau SABH (dulu disebut SISMINBAKUM) adalah jenis pelayanan jasa hukum yang diberikan kepada masyarakat dunia usaha dalam proses pengesahan badan hukum PT, pemberian persetujuan perubahan anggaran dasar PT, penerimaan pemberitahuan perubahan anggaran dasar PT dan perubahan data PT, serta pemberitahuan informasi lainnya secara elektronik (melalui jaringan komputer dan internet), yang diselenggarakan oleh Direktorat Jenderal Administrasi Hukum Umum (Ditjen AHU) pada Kementerian Hukum dan Hak Asasi Manusia Republik Indonesia. ${ }^{5}$

Sistem Administrasi Badan Hukum (SABH) pada awalnya dikenal dengan sebutan SABH yang merupakan suatu sistem online yang diciptakan oleh Kementerian Hukum dan Hak Asasi Manusia Republik Indonesia, untuk mempercepat proses pengesahan badan hukum Perseroan Terbatas, persetujuan anggaran dasar maupun pelaporan anggaran dan atau data Perseroan Terbatas. Pembentukan Sistem Administrasi Badan Hukum (SABH)merupakan suatu bentuk optimalisasi pelayanan hukum oleh pemerintah kepada masyarakat yang dilakukan dengan menggunakan jejaring teknologi informasi secara online, dimana Kementerian Hukum dan Hak Asasi Manusia Republik Indonesia khususnya Direktorat Jenderal Administrasi Hukum Umum terus bergerak memberikan pelayanan terbaik kepada masyarakat. ${ }^{6}$

Penerapan Sistem Administrasi Badan Hukum (SABH) adalah prosedur permohonan pengesahan Badan Hukum Perseroan Terbatas (PT) dengan menggunakan komputer atau dengan fasilitas home page / website. Anggota atau pelanggan SABH adalah Notaris, Konsultan hukum dan pihak lain yang telah memiliki username dan kode password tertentu serta telah memenuhi persyaratan administratif yang ditetapkan berdasarkan keputusan Ditjen AHU.

Proses pengesahan badan hukum perseroan dalam Sistem Administrasi Badan Hukum melalui online yang dilakukan oleh Notaris dimana Notaris cukup dengan mengakses program aplikasi Sistem Administrasi Badan Hukum secara online. Dalam rangka melakukan proses pendaftaran Perseroan menjadi badan hukum tidak selamanya berjalan mulus, seperti

\footnotetext{
${ }^{5}$ Dwi Hariyani, R.Serfianto Dibyo Purnomo dan Cita Yustisia Serfiyani., Panduan PraktisSABH Sistem Administrasi Badan Hukum, Yogyakarta, Pustaka Yustisia, Cetakan Pertama, 2011, hal.13.

${ }^{6}$ SABH-NG Menjawab Tantangan Zaman, Diapresiasi Banyak Negara, Majalah RenvoiNomor 7/79, Desember Th 07/2009.
} 
mengalami gangguan pada jaringan, hal ini mengakibatkatkan terhambatnya proses permohonan pengesahan badan hukum Perseroan Terbatas sehingga mengakibatkan tertundanya proses permohonan pengesahan badan hukum Perseroan Terbatas.Keterlambatan dalam proses pengesahan Perseroan Terbatas dapat disebabkan oleh;

1. SABH yang masih kurang cepat dan kurang akurat;

2. Kelalaian Notaris dalam pengisian Data Pengesahan PT pada SABH;

3. Keterlambatan data dari pihak pendiri Perseroan Terbatas.

4. Gangguan pada sistem jaringan atau pada server aplikasi SABH

Berdasarkan uraian latar belakang ini dan untuk menjawab mengenai peranan Notaris dalam proses pengesahan pendirian perseroan terbatas melalui Sistem Administrasi Badan Hukum $(\mathrm{SABH})$, yang dituangkan dalam judul Jurnal :"Peranan Notaris Dalam Pengesahan Pendirian Perseroan Terbatas Melalui Sistem Administrasi Badan Hukum (SABH) "yang nantinya diharapkan dapat memberikan saran dan masukanterhadap praktek Notaris khususnya dan lembaga kenotariatan umumnya, serta lembaga yang terkait dalam penegakan hukum di Indonesia.

\section{Perumusan Masalah :}

Berdasarkan uaraian latar belakang diatas, maka dapat dirumuskan pokok-pokok permasalahan sebagai berikut:

1. Bagaimana tanggungjawab notaris terkait Pelaksanaan Pendirian dengan sistem administrasi badan hukum (SABH) secara elektronik?

2. Apa saja kendaladan upaya penyelesaian yang dihadapi dalam pendaftaran online dengan sistem administrasi badan hukum (SABH) secara elektronik?

\section{Metode Penelitian}

Tipe penelitian ini merupakan penelitian yuridis empiris.karena dalam penelitian tersebut berkaitan dengan pendapat dan perilaku masyarakat dalam hubungan hidupnya. Dengan kata lain, penelitian empiris ini mengungkapkan implementasi hukum yang hidup dalam masyarakat melalui perbuatan yang dilakukan oleh masyarakat

Penelitian empiris ini bertujuan untuk mengetahui sejauh mana bekerjanya hukum dalam kehidupan masyarakat.Pangkal tolak penelitian empiris adalah fenomena hukum masyarakat atau fakta sosial yang terdapat dalam masyarakat. Menurut Durkheim faktor sosial adalah suatu kebiasaan, pedoman perilaku atau tata cara yang memiliki sifat (a) Berada diluar individu; yaitu tidak tunduk pada keingingan individu dan keberadaannya lebih lama dari keberadaan tiap individu. (b) Memiliki kekuatan memaksa; yaitu memiliki kekuatan untuk mengarahkan dan menentukan perilaku individu jika dilanggar akan terkena sanksi. (c) Universal; yaitu mengikuti semua individu atau sebagian besar individu dalam masyarakat. Dengan sifat objektif yang demikian, pendapat Emil Durhkeim menyatakan bahwa fakta sosial sebagai obyek kajian sosiologi, dapat ditangkap dan diolah dengan metodologi yang berlaku dalam ilmu eksakta, sedangkan fakta yang bersifat subyektif dan kualitatif telah 
terwakili dalam fakta yang obyektif dan bersifat kuantitatif. Hal ini merupakan ciri atau karakter penelitian empiris yang secara lengkap meliputi (a) Pendekatannya pendekatan empiris. (b) Dimulai dengan pengumpulan fakta-fakta sosial/fakta hukum. (c) Pada umumnya menggunakan hipotesis untuk diuji. (d) Menggunakan instrumen penelitian (wawancara, kuesioner).(e) Analisisnya kualitatif, kuantitatif, atau gabungan keduanya. (f) Bebas nilai, maksudnya tidak boleh terpengaruhi oleh subyek peneliti, atau dengan kata lain tidak boleh tergantung atau terpengaruhi oleh penilaian pribadi dari peneliti. Dari ciri-ciri pengkajian empiris tersebut, terlihat bahwa penelitian empiris lebih menekankan pada segi observasinya ${ }^{7}$.

\section{Pendekatan Penelitian}

Pendekatan yang digunakan dalam penelitian ini adalah pendekatan kualitatif.Pendekatan kualitatif ini adalah pendekatan dimana penelitian tersebut meneliti informan sebagai subyek penelitian dalam lingkungan hidup kesehariannya.Untuk itu, sedapat mungkin berinteraksi dengan informan tersebut.

Pendekatan kualitatif ini memiliki banyak ciri, yakni ${ }^{8}$

1) Bersifat alamiah; maksudnya adalah penelitian ini berlangsung dalam situasi alamiah.

2) Bersifat dinamis dan berkembang. Maksudnya adalah dalam penelitian, peneliti jangan terburu dalam pengambilan kesimpulan, akan muncul sikap alamiah dari subyek jika bertemu lebih dari satu kali.

3) Fokus penelitian, dimana fokus dari penelitian ini terbatas pada tema penelitian.

4) Bersifat deskriptif. Maksudnya adalah penelitian ini melakukan penggambaran secara mendalam tentang situasi atau proses yang diteliti.

5) Sasaran penelitian berlaku sebagai subyek penelitian.

6) Subyek terbatas. Maksudnya adalah orang-orang yang dianggap tahu dengan fenomena yang diteliti ini tidak harus banyak.

7) Mengutamakan data langsung. Maksudnya adalah peneliti sendiri yangterjun langsung untuk melakukan observasi atau wawancara.

8) Perspektik holistik. Maksudnya adalah diperolehnya pemahaman yang menyeluruh dan utuh tentang fenomenaataurealitasyangditelitimeliputiseluruhsisiaktivitassubyekyangditeliti.

9) Analisis data dilakukan secara induktif. Analisis induktif dimulai dengan melakukan serangkaian observasi khusus, yang kemudian akan memunculkan tema atau kategori serta pola-pola hubungan yang telah dibuat.

\section{Lokasi Penelitian}

\footnotetext{
${ }^{7}$ Bahder Johan Nasution, MetodePenlitian Ilmu Hukum, Bandung, Mndar Maju, 2008, hlm 123-125

${ }^{8}$ Muhammad Idrus, Metode Penelitian Ilmu Sosial Pendekatan Kualitatif Dan Kuantitatif, Jakarta, Erlangga, 2009, h. 24-27
} 
Lokasi penelitian merupakan tempat dimana penelitian akan dilakukan. Dengan judul penelitian yang diambil adalah Peranan Notaris Dalam Pengesahan Pendirian Perseroan Terbatas Melalui Sistem Administrasi Badan Hukum (SABH), Peneliti akan melakukan penelitian di beberapa Notaris di Kota Jambi, diantaranya adalah :

1) Notaris/PPAT Firman Gusri S.H. M.kn beralamat kantor di Jalan Gajah Mada No. 16, RT 02, Kelurahan Lebak Bandung, Kecamatan Jelutung. Kota Jambi.

2) Notaris/PPAT Nova Herawati S.H, beralamat kantor di Jalan Dara Petak Nomor 39, RT 04, Kecamatan Jambi Timur, Kota Jambi.

3) Notaris/PPAT Nurhassanah S.H. M.Kn beralamat kantor di Jalan H. Adam Malik, Nomor 48, RT 07, Kelurahan Handil Jaya, Kecamatan Jelutung, Kota Jambi.

4) Notaris /PPAT Winny Firstia S.H. M.Kn, beralamat kantor di Jalan Orang Kayo Pingai, Nomor 51, RT 09, Kelurahan Talang Banjar, Kecamatan Jambi Timur, Kota Jambi.

\section{Sumber dan Jenis Data}

Sumber data adalah subjek dari mana data diperoleh. Adapun yang dipakai dalam penelitian ini adalah sebagai berikut :

\section{a. Data Primer}

Sumber data primer adalah data yang diperoleh dari yang pertama wawancara dimana wawancara ini adalah salah satu sumber data yang akan digunakan peneliti untuk menggali informasi terkait Peran Notaris Dalam Pengesahan Pendirian Perseroan Terbatas Melalui Sistem Administrasi Badan Hukum (SABH). Narasumber yang akan diwawancarai adalah Notaris Firman Gusri SH. M Kn. Kedua adalah Notaris Nova Herawati SH, Ketiga adalah Notaris/PPAT Nurhasanah SH. M kn dan yang terakir adalah Notaris/PPAT Winny Firstia SH. M kn,dalam hal ini penulis ingin mengetahui bagaimana peran Notaris dalam melakukan pendaftaran Perusahaan Terbatas melalui sistem SABH serta apa saja kendala - kendalanya di lapangan. Tujuan dari wawancara ini adalah untuk menggali informasi yang berkaitan dengan penelitian penulis. Kemudian diperkuat dengan data primer kedua berupa dasar hukum dari judul penilitian penulis yaitu .

1. Kitab Undang-undang Hukum Perdata;

2. Kitab Undang-undang Hukum Dagang;

3. Undang-undang Nomor 40 tahun 2007 tentang Undang-undang Perseroan Terbatas;

4. Keputusan Menteri Kehakiman dan Hak Asasi Manusia Republik Indonesia tanggal 4 Oktober 2000 nomor M-01.HT.01.01 tahun 2000 tentang Pemberlakuan Sistem Administrasi Badan Hukum Di Direktorat Jenderal Administrasi Hukum Umum Departemen Kehakiman dan Hak Asasi Manusia Republik Indonesia; 
5. Keputusan Menteri Kehakiman dan Hak Asasi Manusia Republik Indonesia tanggal 12 Juli 2002 nomor M-05.HT.01.01 tahun 2002 tentang Pemberlakuan Sistem Administrasi Badan Hukum Di Direktorat Jenderal Administrasi Hukum Umum Departemen Kehakiman dan Hak Asasi Manusia Republik Indonesia;

6. Peraturan Menteri Hukum dan Hak Asasi Manusia Republik Indonesia tanggal 21 September 2007 nomor M.01-HT.01.10 Tahun 2007 tentang Tata Cara Pengajuan Permohonan Pengesahan BadanHukum Dan Persetujuan Perubahan Anggaran Dasar, Penyampaian Pemberitahuan Perubahan Anggaran Dasar Dan Perubahan Data Perseroan;

7. Peraturan Menteri Hukum dan Hak Asasi Manusia Republik Indonesia tanggal 21 September 2007 nomor M.02.HT.01.10 Tahun 2007 tentang Tata Cara Pengumuman Perseroan Terbatas Dalam Tambahan Berita Negara Republik Indonesia;

8. Peraturan Menteri Hukum dan Hak Asasi Manusia Republik Indonesia tanggal 7 Januari 2008 nomor M-01.HT.01.01 tahun 2008 tentang Daftar Perseroan;

9. Peraturan Menteri Hukum dan Hak Asasi Manusia Republik Indonesia Nomor M.HH-01.AH 01.01 Tahun 2011;

10. Peraturan Menteri Hukum dan Hak Asasi Manusia Republik Indonesia Nomor 04 Tahun 2014;

11. Keputusan Direktur Jenderal Administrasi Hukum Umum Departemen Kehakiman Dan Hak Asasi Manusia RepublikIndonesia tanggal 22 Januari 2003 nomor C-01.HT.01.01. Tahun 2003 tentang Tata Cara Pengajuan Permohonan Dan Pengesahan Akta Pendirian Dan Persetujuan Akta Perubahan Anggaran Dasar Perseroan Terbatas.

Data Sekunder.

Dalam penelitian ini peneliti mendapatkan data sekunder berupa dokumen- dokumen dan literatur (kepustakaan) yang terkait dengan permasalahan yang akan diteliti. Data sekunder yang akan digunakan adalah literatur berupa buku-buku, internet, serta literatur yang membahas mengenai penelitian penulis.

Pendapat lain menjelaskan bahwasanya bahan sekunder adalah semua publikasi tentang hukum yang merupakan dokumen yang tidak resmi. Publikasi tersebut terdiri dari (a) bukubuku teks yang membicarakan suatu dan / beberapa permasalahan hukum, (b) kamus hukum, (c) jurnal-jurnal hukum, (d) komentar para hakim atas putusan hakim. Publikasi ini merupakan petunjuk atau penjelasan mengenai bahan hukumprimer. ${ }^{9}$

Telaah buku-buku klasikpun juga dianjurkan dalam penelitian dan dijadikan bahan sekunder dalam penelitian.Dan sebagai penyeimbang buku-buku baik yang klasik atau kontemporer

${ }^{9}$ Marzuki Mahmud P., Penelitian Hukum, Jakarta, Kencana, 2010, h.155, 162 
artikel yang dimuat dalam jurnal-jurnal hukum layak dijadikan bahan hukum sekunder. ${ }^{10}$

\section{Pembahasan}

\section{Peran Serta Tanggung Jawab Notaris Dalam Pengesahan Badan Hukum Perseroan Terbatas Melalui Sistem Administrasi Badan Hukum.}

Dengan diundangkannya Undang-Undang Nomor 30 Tahun 2004 Tentang Jabatan Notaris (selanjutnya disebut UUJN) sebagaimana dirubah dengan Undang-Undang Nomor 2 Tahun 2014 Tentang Perubahan atas Undang-Undang Nomor 30 Tahun 2004 Tentang Jabatan Notaris (selanjutnya disebut UUJN-P) sebagai peraturan yang mengakomodir jabatan notaris menyatakan Pasal 1 angka 1 UUJN-P notaris adalah "Pejabat umum yang berwenang untuk membuat akta autentik dan memiliki kewenangan lainnya sebagaimana dimaksud dalam undangundang ini atau berdasarkan undang-undang lainnya" 11

Tanggung jawab notaris terhadap pendirian Perseroan Terbatas dimulai dari adanya ketentuan bahwa pendirian Perseroan Terbatas, sebagai suatu perjanjian, dibuat dan dituangkan dalam suatu akta notariil. Pasal 7 ayat (1) UUPT menetapkan bahwa perseroanterdiri oleh 2 (dua) orang atau lebih dengan akta notaris yangdibuat dalam bahasa Indonesia. Dalam Pasal 1868 ditentukansebagai berikut :

"Akta otentik adalah akta yang dibuat dan diresmikan dalam bentuk menurut hukum, oleh atau dihadapanpejabat-pejabat umum, yang berwenang berbuatdemikian, dimana akta itu dibuat”.

Peran notaris sebagai pejabat publik sangat diperlukan dalam mendirikan suatu Perseroan Terbatas sebagai badan usaha yang berbadan hukum, yaitu antara lain dalam :

a. Pembuatan akta pendirian Perseroan Terbatas yang berupa suatu akta autentik;

b. Pengajuan permohonan pengesahan badan hukum Perseroan Terbatas kepada Menteri melalui sistem administrasi badan hukum.

Notaris dalam menjalankan jabatannya selaku pejabat umum selain terikat dengan peraturan jabatan, juga terikat pada sumpah jabatan yang diucapkan pada saat pengangkatan sebagai notaris, dimana notaris wajib untuk merahasiakan isi akta dan keterangan yang diperolehnya. $^{12}$

Sistem Adminitsrasi Hukum Umum (AHU) Online lebih memudahkan pengesahan Badan Hukum Perseroan Terbatas dibandingkan dengan sistem-sistem layanan Badan Hukum yang dahulu. AHU online lebih memudahkan pengesahan badan hukum yang dahulu. AHU online menerapkan pelayanan prima dengan mengutamakan pelayanan yang professional, cepat, tepat, efisien, murah dan bebas pungli.

\footnotetext{
${ }^{10}$ Ibid, hlm 155, 162

${ }^{11}$ Padry.M, Perlindungan Hukum Penerima Protokol Notaris dan Kewajiban Menyimpan Rahasian Jabatan, Recital Review, Magister Kenotariatan Universitas JambiVol 2 No 1 (2020): Volume 2, Nomor 1, Januari 2020.

${ }^{12}$ Padry.M, Op.Cit.
} 
Pada pasal 11 Permenkumham Nomor 4 Tahun 2014, untuk memperoleh keputusan menteri mengenai pengesahan Badan Hukum dan Perseroan, pemohon harus mengajukan permohonan secara elektronik kepada menteri, permohohonan tersebut diajukan paling lama 60 hari terhitung sejak tanggal akta pendirian telah ditandatangani

Alur Pengajuan Permohonan Elektronik terkait Pengesahan dan/atau Perubahan Anggaran Dasar dan/Data Perseroan dalam SABH bila diuraikan sebagai berikut :

a) Setelah akta notaris mengenai pendirian/perubahan anggaran dasar dan/atau data PT ditanda tangani, maka notaris mengajukan permohonan dengan akses online SABH melalui website ahu.go.id diawali dengan melakukan pembelian dan pembayaran voucher Penerimaan Negara Bukan Pajak (PNBP) terkait Pengesahan Badan Hukum PT/Perubahan Anggaran Dasar dan/atau Data Perseroan sebagaimana diatur dalam Peraturan Pemerintah Nomor 10 Tahun 2015 Tentang Perubahan Atas Peraturan Pemerintah Nomor 45 Tahun 2014 Tentang Jenis Dan Tarif Atas Jenis Penerimaan Negara Bukan Pajak Yang Berlaku Pada Kementerian Hukum Dan Hak Asasi Manusia.

b) Setelah melakukan pembayaran atas PNBP terkait maka pemohon akan mendapatkan Nomor voucher untuk melakukan akses terkait Pengesahan Pendirian Badan Hukum/Perubahan Anggaran Dasar dan/atau Data Perseroan Terbatas, sehingga proses selanjutnya adalah mengisi Format Isian Pendirian/Perubahan. Format isian pendirian yang memuat sekurang-kurangnya adalah nama dan tempat kedudukan Perseroan, jangka waktu berdirinya Perseroan, maksud dan tujuan serta kegiatan usaha Perseroan, jumlah modal dasar, modal ditempatkan, dan modal disetor, dan alamat lengkap Perseroan.(UUPT). Sedangkan Format isian perubahan diantaranya jenis perubahan yang hendak dilakukan yakni persetujuan dan/atau pemberitahuan perubahan anggaran dasar dan/atau data perseroan, akta notaris yang menjadi dasar perubahan anggaran dasar, tanggal RUPS/ Berita Acara Rapat/ Notulen Rapat yang memerlukan persetujuan antara lain nama dan tempat kedudukan Perseroan, jangka waktu berdirinya Perseroan, maksud dan tujuan serta kegiatan usaha perseroan, Peningkatan modal dasar, dan status perseroan.

c) Setelah mengisi Format Isian Pendirian/Perubahan pada $\mathrm{SABH}$, notaris akan diminta menyetujui Surat Pernyataan Elektronik yang menyatakan bahwa data pada format isian pendirian/perubahan yang disampaikan dalam permohonan adalah sebenarnya dan keterangan mengenai dokumen pendukung telah sesuai dengan ketentuan peraturan perundang-undangan, pemohon bertanggung jawab penuh dan bersedia menerima segala bentuk sanksi terhadap Format Isian Pendirian/Perubahan Perseroan dan keterangan tersebut.

d) Setelah itu Pemohon dalam hal ini Notaris diminta untuk menggunggah dokumen Pendukung yang dipersyaratkan yaitu Akta Pendirian/Perubahan Anggaran Dasar dan/atau Data Perseroan Terbatas (Permenkunham, 2014).

e) Dalam hal Format Isian Pendirian atau Perubahan Perseroan telah sesuai dengan ketentuan peraturan perundang-undangan, Menterilangsung menyatakan tidak berkeberatan atas permohonan pengesahan dan hukum Perseroan secara elektronik (Permenkunham, 2014). Berdasarkan penjelasan Pasal 10 ayat (3) UUPT permohonan persetujuan atau pemberitahuan perubahan anggaran dasar apabila terdapat dua jenis perubahan anggaran 
dasar dapat dilakukan secara langsung atau bersamaan saat pengajuan. Selain itu Pasal 30 Permenkumham Nomor 4 Tahun 2014 jo Permenkumham Nomor 1 Tahun 2016 mengatur mengenai Pengisian Format Perubahan Anggaran Dasar yang memerlukan persetujuan menteri dan cukup dengan diberitahukan dapat dilakukan secara bersama dengan pengisian Format Perubahan mengenai Data Perseroan.

f) Setelah memperoleh Tidak Keberatan Menteri, maka menteri menerbitkan Keputusan Menteri mengenai Pengesahan badan hukum Perseroan/Keputusan Menteri Persetujuan Perubahan Anggaran Dasar/Surat pemberitahuan perubahan anggaran dasar dan/atau data perseroan dalam jangka waktu paling lama 14 (empat belas) hari sejak tanggal pernyataan tidak keberatan menteri. Keputusan menteri ini disampaikan secara elektronik kepada notaris sehingga notaris dapat langsung melakukan pencetakan tersebut secara mandiri terhadap keputusan menteri mengenai pengesahan badan hukum perseroan/keputusan menteri persetujuan perubahan anggaran dasar/surat penerimaan pemberitahuan perubahan anggaran dasar dan/atau data perseroan.

g) Setelah surat keputusan menteri mengenai pengesahan pendirian badan hukum perseroan dicetak secara mandiri oleh Notaris, sesuai ketentuan Pasal 15 ayat (4) Permenkumham Nomor 4 Tahun 2014 jo Permenkumham Nomor 1 Tahun 2016 surat tersebut wajib ditanda tangani dan dibubuhi cap jabatan oleh Notaris serta memuat frasa yang menyatakan "Keputusan Menteri ini dicetak dari SABH". Hal serupa juga berlaku mutatis mutandis terhadap keputusan menteri persetujuan perubahan anggaran dasar/surat penerimaan pemberitahuan perubahan anggaran dasar dan/atau data perseroan.

Daftar Perseroan pada SABH didasarkan pada permohonan elektronik yang diajukan oleh notaris dengan melakukan pengisian Format Isian Pendirian/Perubahan Anggaran Dasar dan/atau Data Perseroan pada SABH yang didasarkan dokumen pendukung yang utama yaitu Akta Pendirian/Perubahan Anggaran Dasar dan/atau Data Perseroan Terbatas.

\section{Permasalahan Yang Dihadapi Dalam Pendaftaran Online melalui Sistem Adminitrasi Badan Hukum (SABH).}

Hambatan-hambatan yang terjadi dalam pengesahan pendirian Perseroan Terbatas baik pada sistem lama maupun sistem baru diantaranya $:^{13}$

1. Hambatan Teknis

a. Sistem Lama

1) Pada sistem lama dimana seluruh proses dilakukan secara manual, sering timbul masalah keterlambatan, hal ini dikarenakan para petugas harus memeriksa satu persatu permohonan yang masuk, sedangkan jumlah permohonan yang masuk jauh lebih banyak darikapasitas petugas yang ada. Resiko terjadinya human error cukup besar dikarenakan setiap data harus dicocokan kepada dokumen yang cukup banyak.

2) Untuk notaris, sistem lama akan membuat proses menjadi tidak efisien dikarenakan mereka harus melakukan pengecekan ke Departemen Hukum dan Hak Asasi Manusia di Jakarta, ini dikarenakan seluruh proses hanya dapat di lakukan dan dipantau di Jakarta.

${ }^{13}$ Wawancara dengan notaris Winny Firstia, tanggal 28 Januari 2020 
3) Penelusuran terhadap proses yang sedang berlangsung sulit dilakukan karena tidak adanya sebuah sistem online yang dapat memantau proses pembuatan.

4) Proses pengesahan Akta Pendirian Perseroan Terbatas yang dilakukan secara manual berdasarkan ketentuan dalam Keputusan Menteri Kehakiman Nomor M.01-PR.08.01 Tahun 1996, berdasarkan pengalaman selama ini, sulit untuk diselesaikan tepat waktu sesuai dengan ketentuan dalam pasal 9 ayat (2) Undang-Undang Nomor 1 Tahun 1995 (UUPT), yakni dalam waktu paling lama 60 hari (enam puluh) hari setelah permohonan diterima. Hambatan yang terjadi antara lain karena :

- Permohonan yang masuk setiap hari jumlahnya sangat banyak.

- Rumitnya atau banyaknya unsur-unsur dari persyaratan permohonan yang harus dikoreksi secara manual oleh para petugas yang jumlahnya relatif tidak seimbang dibanding dengan jumlah permohonan yang diterima.

b. Sistem Baru

1) Notaris yang beradadi daerah tertentukesulitan untukmelakukan aksesinternet, dikarenakantidak disetiap daerahdi Indonesia sudahmenjangkau teknologiInternet.

2) Adanya faktorSumber DayaManusia, yang berasaldari notaris itu sendiri,yaitu kemampuanalam pengoperasian Internet dan kesalahan human error dari pihak notaris yang salah dalam memasukan data.

3) Rawan terjadi pembobolan data, khusunya oleh para Hacker, yang merupakan pelaku kejahatan Cyber.

2. Hambatan Administratif

a. Sistem Lama (tidak ada)

b. Sistem Baru

Biaya terhadap akses SISMINBAKUM (akses fee) relatif lebih mahal apabila jika dibandingkan dengan sistem lama (manual).

3. Hambatan Yuridis

a. Sistem Lama (tidak ada)

b. Sistem Baru

Berkaitan dengan penggunaan internet, undang-undang di Indonesia belum begitu banyak mengakomodir berbagai permasalahan yang berkaitan dengan pemakaian internet, khususnya mengenai cybercrime dibidang notariat.

Dari hasil wawancara dapat dikatakan bahwa pendaftaran Perseroan Terbatas menggunakan sistem online $(\mathrm{SABH})$ mempunyai hambatan dan memiliki kekurangan pada penggunaannya walaupun tidak hanya praktis, tapi juga lebih cepat dan efisien efektif, ekonomis, transparan dan dapatmeminimalisir atau menghindarkan terjadinyaperbuatan atau tindakan seperti melakukankolusi atau pungutan liar.

\section{Upaya-Upaya Untuk Mengatasi Hambatan-Hambatan Yang Dihadapi Notaris.}

Upaya untuk mengatasi hambatan dalam proses pendafataran pada SABH terdapat dua cara yaitu secara manual dan secara elektronik, yaitu: ${ }^{14}$

1. Secara Manual

${ }^{14}$ Wawancara dengan notaris Wiiny Firstia, tanggal 28 Januari 2020 
Secara garis besar kendala-kendala dan hambatan yang timbul dari sistem manual dalam pengesahan pendirian Perseroan Terbatas dapat diatasi dengan adanya Sistem Administrasi Badan Hukum (SABH) secara elektronik, seperti masalah waktu dan efisiensi dalam hak monitoring terhadap proses ini.

\section{Secara Elektronik Melalui SABH}

a) Mengenai biaya yang relatif lebih mahal, satu-satunya upaya yangdapat dilakukan notaris adalah memberi pemahaman kepada klien, bahwa SABH memasang rate yang berbeda apabiladibandingkan dengan sistem manual. Serta sebaiknya melakukankesepakatan mengenai tahapan pembayarannya oleh klien, karenadalam $\mathrm{SABH}$, tiap tahapan memiliki rate masing-masingyang harus dibayarkan untuk dapat melanjutkan ke tahapanberikutnya, adanya kesepakatan ini untuk menghindarkan klienyang beritikad buruk.

b) Bagi notaris yang berada di daerah tertentu yang kesulitan untukmelakukan akses internet, dikarenakan tidak disetiap daerah diIndonesia sudah menjangkau teknologi Internet, maka hal yangdapat dilakukan hanyalah mengajukan permohonan untuk tetapmengadakan pengesahan pendirian PT secara manual.

c) Mengenai faktor Sumber Daya Manusia, dalam hal ini, maka dapatdilakukan pelatihan-pelatihan mengenai SABH sertainternet itu sendiri, sebenarnya telah ada pelatihan-pelatihanserupa, namun seringkali hal ini tidak efektif, untuk notaris lamamisalnya, lebih memilih hal tersebut diwakilkan terhadap oranglain atau dalam hal ini karyawan yang berada dilingkungankantornya, sehingga pemahaman mengenai dunia cyber dankaitannya dengan SABH tidak mendalam, hal inipenting karena tekhnologi selain membawa dampak positif jugamembawa dampak negatif yang selalu mengikutinya.Ketidakefektifan tersebut juga terlihat pada manajemen pelatihan,dan untuk di daerah-daerah yang seperti kabupaten-kabupaten diluar jawa misalnya, tampaknya belum menyeluruh menjangkaupelatihan ini.

d) Kaitannya dengan penjebolan data, khusunya oleh para Hacker,yang merupakan pelaku kejahatan Cyber, maka sebaiknya ketikanotaris melakukan login terhadap akses $\mathrm{SABH}$, konsepkerahasiaan password itu sendiri harus diperhatikan dan juga tidakserta merta menutup tampilan akses begitu saja, tanpa melakukanLog Out untuk menjaga terjadinya penjebolan data dan penggunaanakses oleh orang lain.

e) Penulis menyadari bahwa kendala mengenai $\mathrm{SABH}$ kuhususnya dalam pembuatan Perseroan Terbatas (PT) dapat dirasakan sendiri oleh Notaris - Notaris, seperti yang penulis lakukan dengan mewawancarai beberapa Notaris di Kota Jambi, penulis menemukan ada banyak kendala - kendala yang dihadapi oleh notaris.

\begin{tabular}{|l|l|l|}
\hline \multicolumn{1}{|c|}{ NOTARIS } & \multicolumn{1}{|c|}{ KENDALA } & \multicolumn{1}{c|}{ SOLUSI } \\
\hline Winny Firstia, S.H.,M.Kn & $\begin{array}{l}\text { Server AHU Online } \\
\text { terkadang sedang } \\
\text { mengalami perbaikan } \\
\text { sistem }\end{array}$ & $\begin{array}{l}\text { Mengirim email ke Ditjen } \\
\text { AHU untuk menanyakan } \\
\text { kapan server bisa normal } \\
\text { kembali atau hanya } \\
\text { menunggu sampai server } \\
\end{array}$ \\
& & \begin{tabular}{l} 
AHU online kembali normal \\
\hline
\end{tabular} \\
\hline
\end{tabular}




\begin{tabular}{|c|c|c|}
\hline & $\begin{array}{l}\text { Jaringan Internet yang } \\
\text { tidak stabil dan } \\
\text { terkadang sangat } \\
\text { lambat. }\end{array}$ & $\begin{array}{l}\text { Sebelum mengakses situs } \\
\text { www.ahu.go.id Notaris } \\
\text { melakukan pengecekan } \\
\text { koneksi internet di dalam } \\
\text { kantor Notaris }\end{array}$ \\
\hline \multirow[t]{3}{*}{ Nurhasanah S.H.,M.Kn } & $\begin{array}{l}\text { Sulitnya berkomunikasi } \\
\text { atau berkonsultasi via } \\
\text { telepon dengan pihak } \\
\text { Ditjen AHU }\end{array}$ & $\begin{array}{l}\text { Mengirim email kepada } \\
\text { Ditjen AHU,namun } \\
\text { diperlukan waktu yang lama } \\
\text { untuk menerima balasan } \\
\text { email dari Ditjen AHU }\end{array}$ \\
\hline & $\begin{array}{l}\text { Masih terjadi server } \\
\text { error pada sistem AHU } \\
\text { online }\end{array}$ & $\begin{array}{l}\text { Menunggu sampai server } \\
\text { kembali normal, karena } \\
\text { sangat sulit untuk } \\
\text { menghubungi pihak AHU }\end{array}$ \\
\hline & $\begin{array}{l}\text { Terkadang terjadi } \\
\text { loading yang begitu } \\
\text { lama dikarenakan } \\
\text { koneksi internet di } \\
\text { dalam kantor sedang } \\
\text { dalam keadaan kurang } \\
\text { baik }\end{array}$ & $\begin{array}{l}\text { Mengganti sementara } \\
\text { koneksi internet dengan } \\
\text { jaringan yang lainnya, agar } \\
\text { tidak terjadi loading yang } \\
\text { lama, namun hal ini tidak } \\
\text { selalu berhasil }\end{array}$ \\
\hline
\end{tabular}

Tabel 1. Kendala dan Solusi Pendirian Perseroan melalui SABH ${ }^{15}$

\section{Kesimpulan}

1. Secara garis besar pendirian $P T$ melalui mekanisme $S A B H$ dimulai dengan dilakukannya permohonan pemesanan nama perseroan dan ditindak lanjuti dengan pembuatan akta pendirian PT. Berdasarkan kuasa yang diberikan oleh para pendiri kepada Notaris sebagai pemohon, pemohon melakukan pembayaran PNBP pengesahan dan BN/TBN. Selanjutnya, dalam jangka waktu 60 (enam puluh) hari terhitung dari tanggal pembuatan akta, Notaris melakukan pengisian data PT dan menyampaikan kepada Kementerian Hukum dan HAM sesuai dengan format SABH secara elektronik. Apabila pengisian data PT dilakukan dengan lengkap dan benar, maka seketika itu juga akan dikeluarkan Surat Pernyataan Elektronik tentang Kebenaran Data Perseroan Terbatas. Setelah itu, akan dikeluarkan Pernyataan Tidak Keberatan oleh Menteri secara online dan dilanjutkan

${ }^{15}$ Wawancara terhadap Notaris Winny Firstia S.H.,M.Kn dan Nurhasanah S.H.,M.Kn pada tanggal 10 Januari 2020 Pukul 11.00 WIB. 
penerbitan SK pengesahan badan hukum oleh Menteri untuk selanjutnya dicetak sendiri oleh pemohon

2. Notaris tidak selalu dapat dimintakan pertanggungjawaban apabila timbul masalah-masalah pada proses pendirian PT dan pengesahan PT melalui SABH. Apabila para pendiri tidak melengkapi berkas pendukung setelah permohonan nama PT disetujui sehingga mengakibatkan kegagalan pendirian PT oleh karena jangka waktu pengunaan nama PT itu expired, maka Notaris tidak dapat imintakan pertanggungjawaban. Namun, apabila Notaris gagal melakukan pemrosesan pendirian dan pengesahan PT melalui SABH setelah para pendiri telah melengkapi semua berkas pendukung yang dibutuhkan untuk pembuatan akta dan proses pengesahan PT, maka Notaris bertanggung jawab secara penuh atas masalah-masalah yang timbul daripadanya, kecuali masalah-masalah tersebut timbul akibat gangguan jaringan atau sistem SABH itu sendiri.

\section{Saran.}

1. Diharapkan Kementerian Hukum dan Hak Azasi Manusia khususnya Direktorat Jenderal Administrasi Hukum Umum (AHU) melakukan peningkatan dalam pelayanan SABH. Menyederhanakan prosedur dan persyaratan pengesahan badan hukum Perseroan Terbatas. Dan lebih di mudahkan dalam pengajuan pengkoreksian data perseroan yang telah terlanjur di sahkan Menteri Hukum dan Hak Azasi Manusia. Dan juga dalam hal peningkatan penyebaran jaringan internet merata di semua daerah di Indonesia dimana hal tersebut membantu Notaris yang ada untuk memudahkan dalam proses pelaksanaan $\mathrm{SABH}$. Kemudian mengenai pengamanan $\mathrm{SABH}$ yang menggunakan jaringan internet agar dijaga dan ditingkatkan bagaimana agar hacker tidak bisa masuk. Kepada para Notaris diharapkan agar lebih murah dalam memberikan biaya pembuatan Perusahaan kepada para pihak yang ingin mendirikan Perusahaan, dikarenakan biaya pada SABH lebih murah dari pada sistem yang sebelumnya.

2. Kepada Notaris agar lebih teliti dan hati-hati sebelum membuat Akta Perseroan Terbatas, Notaris harus dapat mengetahui dan melihat keaslian data data-data Perseroan dalam dalam klausula Akta Pendirian tersebut di tegaskan bahwa syarat-syarat yang telah dilengkapi pendiri benar adanya dan sesuai dengan aslinya dan siap menerima sanksi apabila di kemudian hari ditemukan permasalahan berkaitan hal tersebut. Dalam proses pembuatan akta pendirian perusahaan dan proses pengesahan badan hukum, hal-hal mengenai Teknis berkaitan mengenai waktu, tahap dan biaya-biaya yang diperlukan dalam penyelesaian proses tersebut sebaiknya dijelaskan Notaris dari awal kepada pendiri persero sewaktu Notaris menerima kuasa untuk pendirian dan pengesahan badan hukum, agar hambatan dan keterlambatan yang mungkin terjadi dapat di hindari. Bila ada pihak yang dirugikan pada akibat dari perbuatan hukum Perseroan Terbatas tersebut bukan tidak mungkin Notaris dapat di minta pertanggung jawaban secara Administrasi, Perdata dan bahkan Pidana

\section{DAFTAR PUSTAKA}

\section{Buku}


Marzuki Mahmud P., Penelitian Hukum, Jakarta, Kencana, 2010, h.155, 162

Dwi Hariyani, R.Serfianto Dibyo Purnomo dan Cita Yustisia Serfiyani.,Panduan PraktisSABH Sistem Administrasi Badan Hukum, Yogyakarta, Pustaka Yustisia, Cetakan Pertama, 2011.

Muhammad Idrus, Metode Penelitian Ilmu Sosial Pendekatan Kualitatif Dan Kuantitatif, Jakarta, Erlangga, 2009, h. 24-27

Nasution Johan Bahder, Metode Penelitian Ilmu Hukum, Mandar Maju, Bandung, 2008.

\section{Tesis/Jurnal/Internet/Wawancara}

Putri AR, Perlindungan Hukum Terhadap Notaris (Indikator Tugas-Tugas Jabatan Notaris Yang Berimplikasi Perbuatan Pidana), Jakarta, Sofmedia.

SABH-NG Menjawab Tantangan Zaman, Diapresiasi Banyak Negara, Majalah RenvoiNomor 7/79, Desember Th. 07/2009.

Wawancara dengan notaris Winny Firstia, tanggal 28 Januari 2020

Wawancara terhadap Notaris Winny Firstia S.H.,M.Kn dan Nurhasanah S.H.,M.Kn pada tanggal 10 Januari 2020 Pukul 11.00 WIB.

\section{Peraturan}

Undang-Undang Dasar Negara Kesatuan Republik Indonesia 1945;

Kitab Undang-Undang Hukum Perdata;

Undang-Undang Nomor 30 tahun 2004 tentang Jabatan Notaris.

Undang-Undang Nomor 2 Tahun 2014 Tentang Perubahan atas Undang-Undang Nomor 30 Tahun 2004 Tentang Jabatan Notaris.

Undang-Undang Republik Indonesia, Nomor 40 Tahun 2007 tentang Perseroan Terbatas, LN No.106 Tahun 2007, TLN No. 4756

Peraturan Menteri Hukum dan Hak Asasi Manusia Republik Indonesia Nomor 4 Tahun 2014 Kode Etik Notaris 